\title{
ЭФФЕКТИВНОЕ ВЗАИМОДЕЙСТВИЕ КАК КЛЮЧ К СОВМЕСТНОМУ ПРОЦВЕТАНИЮ
}

\section{EFFECTIVE COOPERATION AS THE KEY TO SHARED PROSPERITY}

\section{N. Zavyalova \\ Zhao Houfu}

Summary: The article demonstrates the way of effective interaction between representatives of various spheres of the modern economic and educational space. The synergy of knowledge is designed to stimulate the process of sustainable development and mutually beneficial enrichment.

Keywords: synergy, interaction, sustainable development, life-long learning, cooperation.
Завьялова Наталья Алексеевна

Д.культурологии, к.филол.н., дочент, ФГБОУ «Уральский государственный экономический университет»,

г. Екатеринбург

n.zavzav@yandex.ru

Чжаоу Хоуфу

Аспирант, ФГБОУ «Красноярский государственный аграрный университет», Красноярск

Аннотация: В статье продемонстрирован путь эффективного взаимодействия представителей различных сфер современного экономического и образовательного пространства. Синергия знаний призвана стимулировать процесс устойчивого развития и взаимовыгодного обогащения.

Ключевые слова: синергия, интеракция, устойчивое развитие, образование в течение жизни, кооперация.

профессиональным увлечением малой группы людей с особыми способностями. В целом следует констатировать тот факт, что высокий уровень заработной платы программистов, блестящие карьерные перспективы являются сильнейшей мотивационной базой для притока молодых специалистов [5]. Остановимся подробнее на языке программирования Java. Интерес к программированию на языке Java не спадает, поскольку программы, написанные на этом языке, поддерживаются всеми устройствами, кросс-платформенными приложениями, входят в диапазон самых разнообразных продуктов от десктопных приложений до банковских ІТ-продуктов. Большинство приложений под Android разрабатываются на Java, этот язык востребован приложениями в коммерческом секторе. Современная экосистема Java прекрасно развита, она адаптируется к новым условиям, обновленные версии JDK выходят каждые полгода. Однако следует отметить, что наряду с интересом к Java, существует и немалый отток из этого языка молодых кадров, чьи ожидания не оправдываются уровнем сложности работы. Мы полагаем, что снижением порога сложности может стать активное овладение английским языком на начальном этапе программирования. Именно знание естественного языка может существенно облегчить доступ к набору методов, их синтаксису для программистов-новичков [6].

Разрабатывая подходы к изучению английского языка с целью применения полученных знаний для программирования на Java, отметим, что для студентовпрограммистов ответы на вопросы о мотивации, целях изучения английского языка как иностранного очевидны. Английский язык является для них языком входа в специальные профессиональные компетенции [7]. 
В рамках данного исследования, мы также уделяем внимание обратному направлению: от преподавателя английского языка к языку программирования Java. Haправления описания и анализа представлены на рис.1

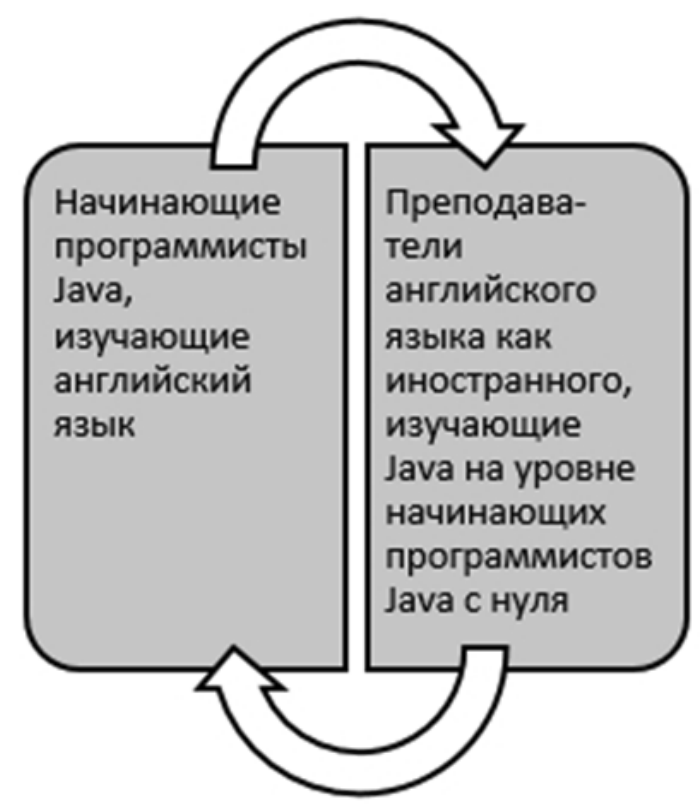

Рис. 1. Блок-схема архитектуры синергии программистов и преподавателей иностранного языка

Если для программистов ситуация выигрыша от изучения английского языка очевидна, то преподаватели английского языка как иностранного могут усомниться в целесообразности получения новых компетенций [8]. Самым очевидным плюсом, на наш взгляд, является улучшение общей эрудиции и имиджевой составляющей в результате предлагаемого проекта для преподавателей английского языка. Среди дополнительных плюсов следует выделить эффект новизны, овладение основами востребованных на рынке труда умений и навыков. Для роста профессиональных навыков педагогов иностранного языка могут быть полезными навыки работы с массивами и их распределением, суть которых очень подробно представлена в наборе базовых знаний Java. Безусловно, для многих преподавателей английского языка изучение Java является новым рубежом, вызовом с неясными целями. Однако следует утверждать, что, исходя из подходов современной позитивной психологии, обучение новым востребованным на рынке труда навыкам помогает в целом повысить эмоциональную составляющую не только профессиональной деятельности, но и личностного мироощущения.

Для того, чтобы более полно представить мотивационную структуру преподавателей английского языка при знакомстве с основами программирования на Java, мы составили опросник, который содержал высказывания преподавателей английского в ходе освоения курса. Эти высказывания необходимо было проранжировать. В опросе приняли участие 7 человек.

Обработка данных опроса выявила повышенный уровень удовлетворенности процессом обучения среди преподавателей иностранного языка. Подобная синергия знаний способствует многостороннему развитию профессиональной личности, что ведет к общему улучшению качества жизни. Вопросы междисциплинарной синергии уже давно находятся в центре внимания современной педагогики [9]. Ученые уделяют большое внимание направлениям, связанным с пониманием взаимодействия близкородственных направлений. В рамках предлагаемого подхода предпринимается попытка синергии неблизкородственных дисциплин: английского языка как иностранного и обучению основам программирования на языке Java. Предпринимаемая попытка синергии двух направлений обусловлена популярностью обоих дисциплин в школьных и вузовских курсах. Английский язык для программистов на языке Java является необходимым источником команд и методов, позволяющим достигать различных целей. Успешное овладение компетенциями программиста обусловлено знанием базовых команд на английском языке. Практика показывает, что нередко эти базовые команды запоминаются начинающими программистами механически. Невозможность запомнить большой массив англоязычных команд нередко приводит к тому, что новички в программировании отстают или вовсе бросают изучение Java. Гипотеза 1 исследования заключается в том, что активная семантизация (перевод и объяснение на русский язык) базовых команд на языке Java на начальном этапе позволит снизить порог сложности для программистовновичков, вскроет глубинные пласты смыслов, заложенных в базовый набор методов. Гипотеза 2 заключается в том, что для преподавателей английского языка как иностранного подобный опыт будет связан с улучшением общего эмоционального фона, он будет способствовать снижению профессионального выгорания. Гипотеза 3 исследования заключается в том, что общая ситуация от подобного образовательного процесса может быть названа ситуацией успеха для обеих сторон.

Важно отметить, что ограничением на участие в подобной программе может быть личное сформированное стойкое нежелание преподавателей английского языка как иностранного изучать язык программирования Java. В подобных случаях следует выяснить причины сформированной демотивации. Базовой установкой в подкреплении мотивации на занятиях следует считать возможность использовать английский язык на всем этапе обучения (Рис. 3).

В качестве решения проблемы мотивационной недостаточности, на наш взгляд, также следует раскрыть важнейшие направления, которые актуализируются во время знакомства с принципиально новой сферой знаний. 
Таблица 1.

Эмоциональные реакции на занятиях по освоению языка Java

\begin{tabular}{|c|c|c|c|c|c|c|}
\hline Суждения & $\begin{array}{c}\text { Полностью } \\
\text { согласен }\end{array}$ & $\begin{array}{l}\text { В целом со- } \\
\text { гласен }\end{array}$ & $\begin{array}{l}\text { Частично } \\
\text { согласен }\end{array}$ & $\begin{array}{c}\text { Частично не } \\
\text { согласен }\end{array}$ & $\begin{array}{c}\text { В целом не } \\
\text { согласен }\end{array}$ & $\begin{array}{l}\text { Полностью не } \\
\text { согласен }\end{array}$ \\
\hline $\begin{array}{l}\text { 1. Изучение основ Java делает меня более } \\
\text { трудолюбивым }\end{array}$ & & & 4 & 2 & 1 & \\
\hline 2. Java - интересная сфера моей деятельности & & 3 & 4 & & & \\
\hline $\begin{array}{l}\text { 3. Когда у меня возникают проблемы при со- } \\
\text { ставлении кода на Јаvа, я продолжаю пробовать } \\
\text { устранить ошибки самостоятельно }\end{array}$ & & & 6 & 1 & & \\
\hline $\begin{array}{l}\text { 4. Когда у меня возникают проблемы при } \\
\text { составлении кода на Јava, я жду помощи от пре- } \\
\text { подавателя }\end{array}$ & & & 1 & 6 & & \\
\hline $\begin{array}{l}\text { 5. Когда у меня возникают проблемы при состав- } \\
\text { лении кода на Јаvа, я испытываю беспокойство }\end{array}$ & 1 & & & 6 & & \\
\hline $\begin{array}{l}\text { 6. Я могу понимать содержание базовых раз- } \\
\text { новидностей кода на Јаvа и испытываю радость, } \\
\text { прилив сил }\end{array}$ & & & 7 & & & \\
\hline
\end{tabular}

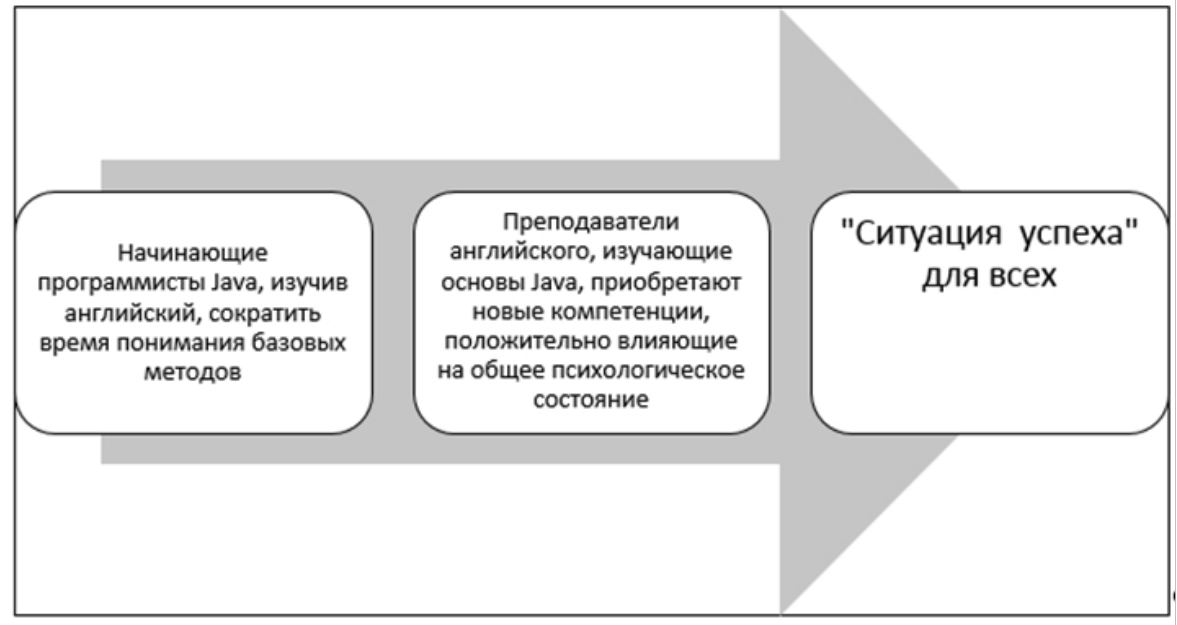

Рис. 2. Ситуация успеха на разных этапах взаимодействия программистов и преподавателей иностранного языка

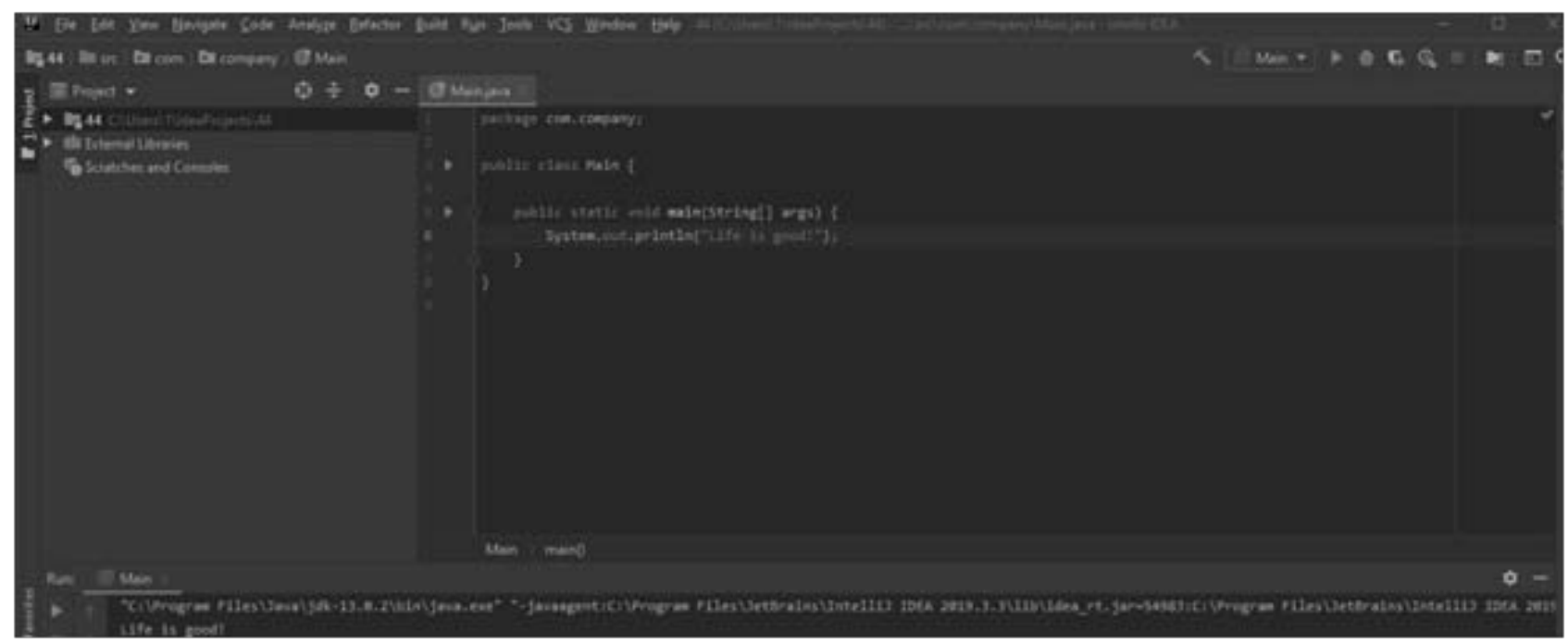

Рис. 3. Образец использования английского языка в синтаксисе Java. 
Предлагаемый план обсуждения сфокусирован на семи областях: 1) отношение социума к процессу обучения; 2) формирование учебной среды; 3) психологическое разнообразие учащихся; 4) формирование учебного плана; 5) планирование и оценка результатов; 6) общественные взаимосвязи; 7) личностный рост и профессиональное развитие.

Мы полностью убеждены в том, что овладение востребованным языком программирования позволит преподавателям достичь следующих уникальных целей:

1. Повышение социально-имиджевой составляющей преподавателя иностранного языка. Продвигаясь в деле освоения языка программирования, преподаватели превращаются в положительные и мощные ролевые модели, могут стать примером человека, который не боится попробовать нечто новое.

2. Преподаватель, осваивающий новые направления, может формировать и познавать современную среду обучения, вырабатывая подобным образом эмпатию по отношению к собственным ученикам, осознавая их трудности и проблемы.

3. Преследуя собственные цели в процессе обучения языкам программирования, преподаватель имеет возможность более полно понимать цели своих студентов при изучении иностранных языков.

4. Наблюдая за работой преподавателей программистов, преподаватель иностранных языков получает опыт взаимодействия с коллегой по точным наукам, что может расширить имеющиеся навыки планирования, оценки и отчетности, мониторинга и архитектуры учебных курсов.

Синергия программистов и преподавателей становится важнейшим компонентом современной образовательной среды, призванной стереть грани между гуманитарными и точными науками. Подобная синергия создает взаимную ситуацию успеха для представителей современного глобального образовательного пространства.

\section{ЛИТЕРАТУРА}

1. Гудова, М.Ю., Гузикова, М.О. (2019) Модель полиязычного образования в университете: критическая теория грамотности и опыт Китая // Отечественная и зарубежная педагогика. № 2 (64). С. 186-199.

2. Завьялова, Н.А. (2015). Культурно-коммуникативные универсалии как современный этап развития культуры // Знание. Понимание. Умение. № 1. C. 77-88. DOI: 10.17805/zpu.2015.1.7

3. Завьялова, Н.А. (2016). Повторяющиеся культурные микроконтексты: диахронный и синхронный аспекты//Знание. Понимание. Умение. № 2. С. 124-137

4. Карасик, В.И. (2009) Языковые ключи. М.: Гнозис. 406 с.

5. Костина, А.В. (2008) Тезаурусный подход как новая парадигма гуманитарного знания//0бсерватория культуры. № 5. С. 102-109.

6. Луков, В.А., Луков, Вл.А. (2008) Тезаурусы: Субъектная организация гуманитарного знания. М.: Изд-во Нац. ин-та бизнеса. 784 с.

7. Орлова, Э.А. (2010) История антропологических учений: учебник для студентов пед. вузов. М.: Академ. Проект; Альма Матер. 621 с.

8. Пелипенко, А.А. (2011) Дуалистическая революция и смыслогенез в истории / предисл. А.С. Ахиезера. 2-е изд., испр. М.: Книжный дом «ЛИБРОКОМ». 384 с.

9. Томберг, 0.В. (2020) Диалогизм и культурный трансфер в древнеанглийской поэтической традиции. Вестник Московского городского педагогического университета. Серия: Филология. Теория языка. Языковое образование. № 3 (39). С. $70-78$. 